\title{
Influence of ridge cultivation and phacelia intercrop on weed infestation of root vegetables of the Asteraceae family
}

\section{Marzena Błażewicz-Woźniak*, Mirosław Konopiński}

Department of Cultivation and Fertilisation of Horticultural Plants

University of Life Sciences in Lublin

Leszczyńskiego 58, 20-068 Lublin, Poland

\begin{abstract}
The field experiment focused on three high-inulin vegetable crops: chicory (Cichorium intybus L. var. sativum Bisch.), black salsify (Scorzonera hispanica L.) and common salsify (Tragopogon porrifolius L.), and took into account two cultivation methods (flat soil and ridges) and a phacelia (Phacelia tanacetifolia L.) intercrop, the biomass of which was mixed with the soil during pre-winter ploughing. Cultivation without an intercrop served as the control. The studies aimed at evaluating the influence of ridge cultivation using a phacelia intercrop on the species composition and population of vegetable weeds as compared to traditional flat-soil cultivation with no intercrop. In total, 24 taxa in the primary and 31 taxa in the secondary weed populations (mostly characteristic for vegetable crops) were recorded in high-inulin species plantations. Monocarpic species such as Senecio vulgaris, Chenopodium album and Lamium amplexicaule dominated in the spring, while Stellaria media, Capsella bursa-pastoris and Urtica urens were most numerous at the end of the vegetation period. Applying phacelia as the intercrop and ploughing its biomass before winter significantly reduced the primary weed population for all of the cultivated crop species as compared to the no-intercrop cultivations. Phacelia grown as the intercrop reduced the occurrence of Senecio vulgaris, while favouring the development of Lamium amplexicaule. The cultivation system affected the primary weed infestation of vegetables, whereas it had no impact on the level of secondary weed infestation. At the beginning of the vegetation periods, fewer weeds grew in ridges than in the flat soil system. The crop species had no effect on the primary weed infestation, while it influenced weed numbers in the secondary. The lowest number of weeds was recorded in the secondary weed infestation of chicory, the well-developed leaf rosettes of which efficiently eliminated most of the weeds.
\end{abstract}

Key words: flat-soil cultivation, ploughing, catch-crop, chicory, black salsify, common salsify

\section{INTRODUCTION}

Inulin is a valuable polysaccharide with specific dietary features. Species of the Asteraceae family are distinguished by high levels of inulin. This group includes chicory, black salsify and common salsify. These plants accumulate inulin in the roots, thus achieving high yields of good-quality roots is a prerequisite in their cultivation. The ridge cultivation of root crops has been re-discovered lately, because it allows very beneficial conditions for growth. Elevating the plant's stand above the natural ground level contributes to higher soil temperatures, deeper root penetration, and their 
better development (Sady and Cebulak 2000, Konopiński 2003, Konopiński and BłażewiczWoźniak 2008, Krause et al. 2009). However, due to drying, cultivation on ridges can be recommended mainly for wet or heavier soils, or with irrigation provided (Konopiński 2003, Babik et al. 2004, Adamicki et al. 2005). The intercrops, an excellent source of organic matter, also change the physical and chemical properties of the soil along with its biological activity. Modifying the soil environment affects not only the growth and yielding of a crop, but also the emergence and growth of weeds (Liebman and Dyck 1993, McGiffen et al. 2000, Błażewicz-Woźniak 2004, Błażewicz-Woźniak and Mitura 2004, Kęsik and Błażewicz-Woźniak 2007, Dhimaa et al. 2009, Kęsik et al. 2010). The present study aimed at evaluating the influence of ridge cultivation using a phacelia intercrop on the species composition and population of weeds in chicory, black salsify, and common salsify crops, as compared to traditional cultivation on flat soil with no intercrop.

\section{MATERIAL AND METHODS}

The field experiments were carried out in 2006-2008 at the Felin Experimental Farm, University of Life Sciences in Lublin (Poland, 51 ${ }^{\circ} 23^{\prime} \mathrm{N}, 2^{\circ} 56^{\prime} \mathrm{E}$ ), on lessive soil developed from moderate dusty loam. The experimental plants were three high-inulin root vegetables species of the Asteraceae family: 'Polanowicka' chicory (Cichorium intybus L. var. sativum Bisch.), 'Duplex' black salsify (Scorzonera hispanica L.) and 'Mamut' common salsify (Tragopogon porrifolius L.). The experiment was set up by means of completely randomised blocks in four replicates. Each experimental plot was 20 $\mathrm{m}^{2}$ in area.

The studies involved two cultivation methods: on flat soil and on ridges, as well as an intercrop made of phacelia (Phacelia tanacetifolia L.), the biomass of which was mixed with the soil during pre-winter ploughing and applied. Plants with no intercrop served as the control.

Winter wheat was the fore-crop. In the year prior to vegetable cultivation, phacelia was sown in the amount of $50 \mathrm{~kg} \mathrm{ha}^{-1}$ in mid-August after the pre-sowing tillage set, which was according to the experimental design. Traditional deep ploughing (using a mouldboard plough) up to $25 \mathrm{~cm}$ in depth was made before the winter. In spring, after presowing the tillage, ridges were formed in one half of the experimental plots. Mineral nutrition was applied in the spring in amounts of: $\mathrm{N}-100 \mathrm{~kg}$, $\mathrm{P}-44 \mathrm{~kg}$ and $\mathrm{K}-124.5 \mathrm{~kg} \mathrm{ha}^{-1}$. Phosphorus in the form of triple superphosphate and potassium as potassium salt were introduced into the soil as a whole before sowing, while nitrogen, in the form of ammonium nitrate, was divided into two equal doses: half before sowing and half as topdressing.

Vegetable seeds were sown on 10 May into rows with $50 \mathrm{~cm}$ spacing and $1.5 \mathrm{~cm}$ deep in the amounts of: chicory $-5 \mathrm{~kg} \mathrm{ha}^{-1}$, black salsify - $12 \mathrm{~kg} \mathrm{ha}^{-1}$ and common salsify $-20 \mathrm{~kg} \mathrm{ha}^{-1}$. The experiment was carried out using the recommended protective measures and fertilisation for the tested species. After sowing, Kerb 50WP herbicide (propyzamide $50 \%$ ) was applied by spraying $\left(2 \mathrm{~kg} \mathrm{ha}^{-1}\right)$. Manual weed control was performed twice a year during the vegetation period. The following fungicides were used against fungal diseases: Bravo 500SC (chlorotalonil) (10 July) and Nimrod 25EC (bupirymat) (18, 27 July and 29 August). The first vegetable seedling emergence was recorded 10-12 days after the sowing date. Thinning was carried out a month after the emergence. The weather conditions during the cultivation period are shown in Table 1.

The weed numbers were determined every year on two dates. The first weed number assessment was performed at the beginning of the plant vegetation period (21 June 2006, 18 June 2007 and 11 June 2008) by determining the "primary

Table 1. Mean monthly air temperatures and amount of precipitation at ES Felin in the years 2006-2008

\begin{tabular}{crrrrrrrr}
\hline & \multicolumn{3}{c}{$\begin{array}{c}\text { Temperature } \\
\left({ }^{\circ} \mathrm{C}\right)\end{array}$} & \multicolumn{3}{c}{ Amount of precipitation } \\
$(\mathrm{mm})$
\end{tabular}


weed infestation", whereas the "secondary weed infestation" was evaluated on 20 September 2006, 18 September 2007 and 20 September 2008. The number of weeds of each species, divided into short-term and perennial ones, was counted per square metre by means of the quantitative method (frame method) in four replications. The results were statistically processed by means of variance analysis. Difference significance was determined using the Tukey test at $\mathrm{p}=0.05$.

\section{RESULTS AND DISCUSSION}

\section{Primary weed infestation}

In total, 24 weed species were recorded as the primary weed infestation in 2006-2008, including 17 monocarpic and seven polycarpic ones (Tabs 2 and 3). Senecio vulgaris L., Chenopodium album L. and Lamium amplexicaule L. were the most numerous representatives. Amongst the perennial species, Taraxacum officinale F.H.Wigg. and Artemisia vulgaris L. dominated. Applying the phacelia intercrop had no influence on weed species number recorded in the studied objects. However, differences in species composition were found. Senecio vulgaris was the most numerous (19.33 plants per $\mathrm{m}^{-2}$, on average) when cultivated without any intercrop. Phacelia reduced the number of this weed species up to 6.22 plants per $\mathrm{m}^{2}$, while it exerted no impact on the occurrence of Chenopodium album, which grew as numerously as in cultivation without the intercrop. Lamb's quarters is an expansive weed with great abilities to adapt to habitat conditions and produces large quantities of seeds that can germinate during the entire vegetation period (Wesołowski 1981, Rola and Rola 1996). The phacelia intercrop favoured the occurrence of Lamium amplexicaule, which was almost twice as common in these objects as in traditional cultivation. When soil was mixed with rye and Vicia villosa L., Anyszka and Dobrzański (2008) reported lower Lamium amplexicaule weed numbers in leek as compared to cultivation with no cover crops. Many crops, due to the allelopathic substances released, may have inhibitive interaction towards selected weed species (Khalid et al. 2002). Of the perennial species grown without an intercrop, Artemisia vulgaris was the most numerous, while the largest numbers of Taraxacum officinale plants were recorded in combination with phacelia.

When the phacelia intercrop was ploughed before winter, it significantly decreased the primary weed infestation amongst the studied vegetables, from 46.2 plants per $\mathrm{m}^{2}$ with no intercrop cultivation to 31.4 plants when the intercrop was applied (Tab. 4). Such dependence was observed for all of the experimental plant species, while it was the most prominent for chicory, where phacelia application lowered the primary weed number by over half. A reduction in the influence of phacelia manifested namely in the case of monocarpic weed species. For perennial weeds, such effects were not statistically confirmed. Other studies (Ngouajioa et al. 2003, Błażewicz-Woźniak 2003, 2004, Teasdale et al. 2007) confirmed a lower primary weed infestation on the vegetable growth after applying cover crops and mixing their biomass with the soil as compared to cultivation with no intercrop. Applying the phacelia intercrop in carrot cultivation lowered the weed number from 94.5 plants without intercrop up to 27.8 plants per $\mathrm{m}^{2}$ (Błażewicz-Woźniak 2004). Franczuk et al. $(2008,2010)$ reported a beneficial effect of phacelia in reducing the weed number in cabbage. The intercrop plants produce large quantities of biomass and create compact canopies, by which they inhibit weed development and show weed control properties towards successive plants (Płaza et al. 2008).

The tillage system also affects the weed amounts through the transfer of weed seeds within the soil profile (Carter and Ivany 2006). When a plant is developed, weed seeds are distributed in a different way than at traditional spring cultivation. In the analysed experiment, there were three weed species more in the plants cultivated in a traditional manner than amongst the plants grown in ridges (Tabs 2 and 3). During flat soil cultivation, Chenopodium album, Senecio vulgaris and Gnaphalium uliginosum L. were more abundant, while Lamium amplexicaule grown in ridges increased its number only in combination with intercrop application; without the intercrop, the species was more numerous in the flat soil cultivation system. Soil in ridges is more dried out, thus species with greater water requirements - such as Gnaphalium uliginosum - were more numerous in flat cultivation in the spring. More perennial species were recorded in ridges than in traditional cultivation. Artemisia vulgaris was more numerous, as was Taraxacum officinale in combination with phacelia. Energetic tillage during ridge formation caused the cutting of the runners and roots of perennial weeds. The absence of Stellaria media (L.) Vill., Conyza canadensis (L.) Cronq. and Thlaspi arvense L. in ridges and Lamium purpureum L. and Elymus repens (L.) Gould in flat 


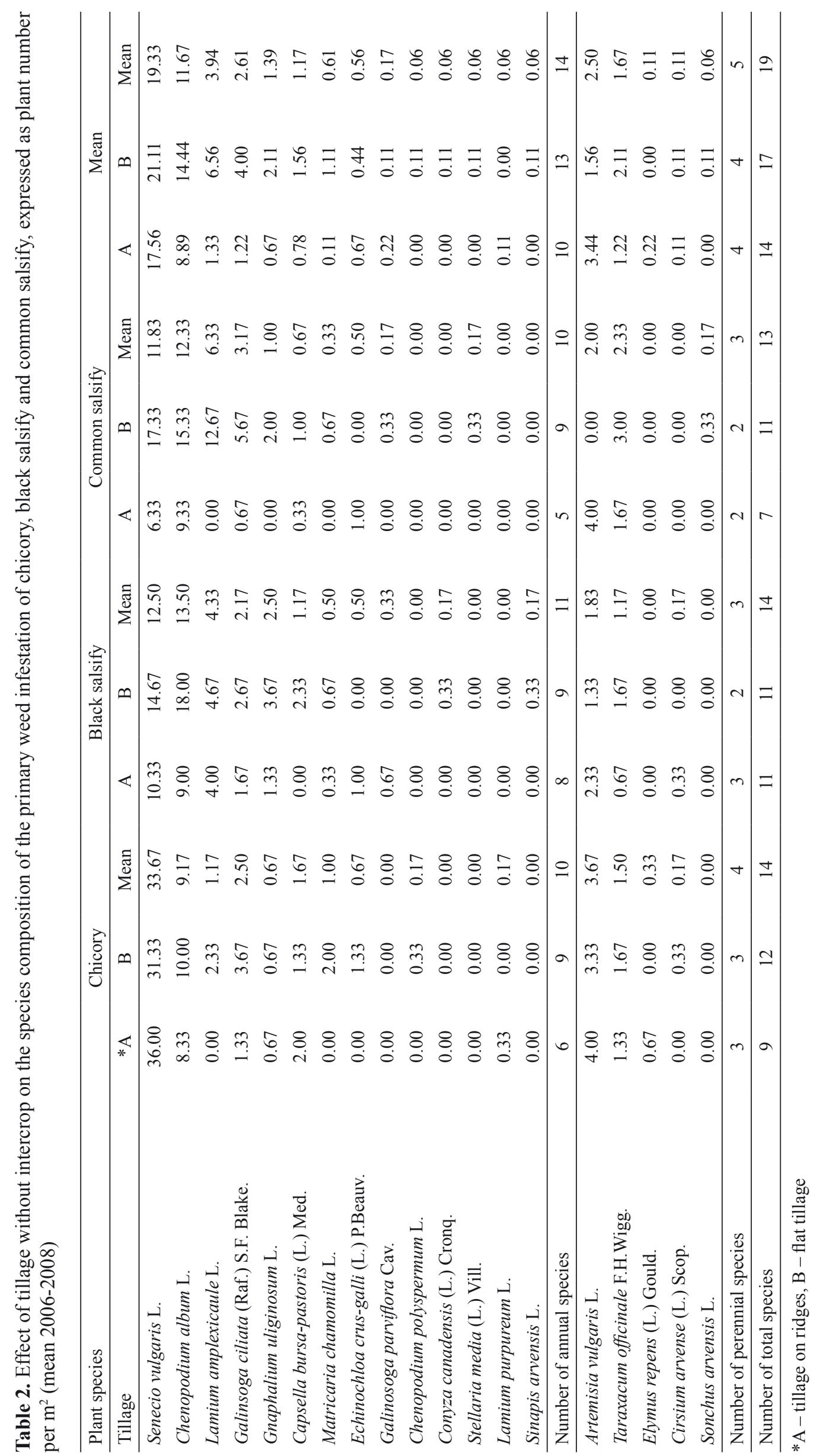




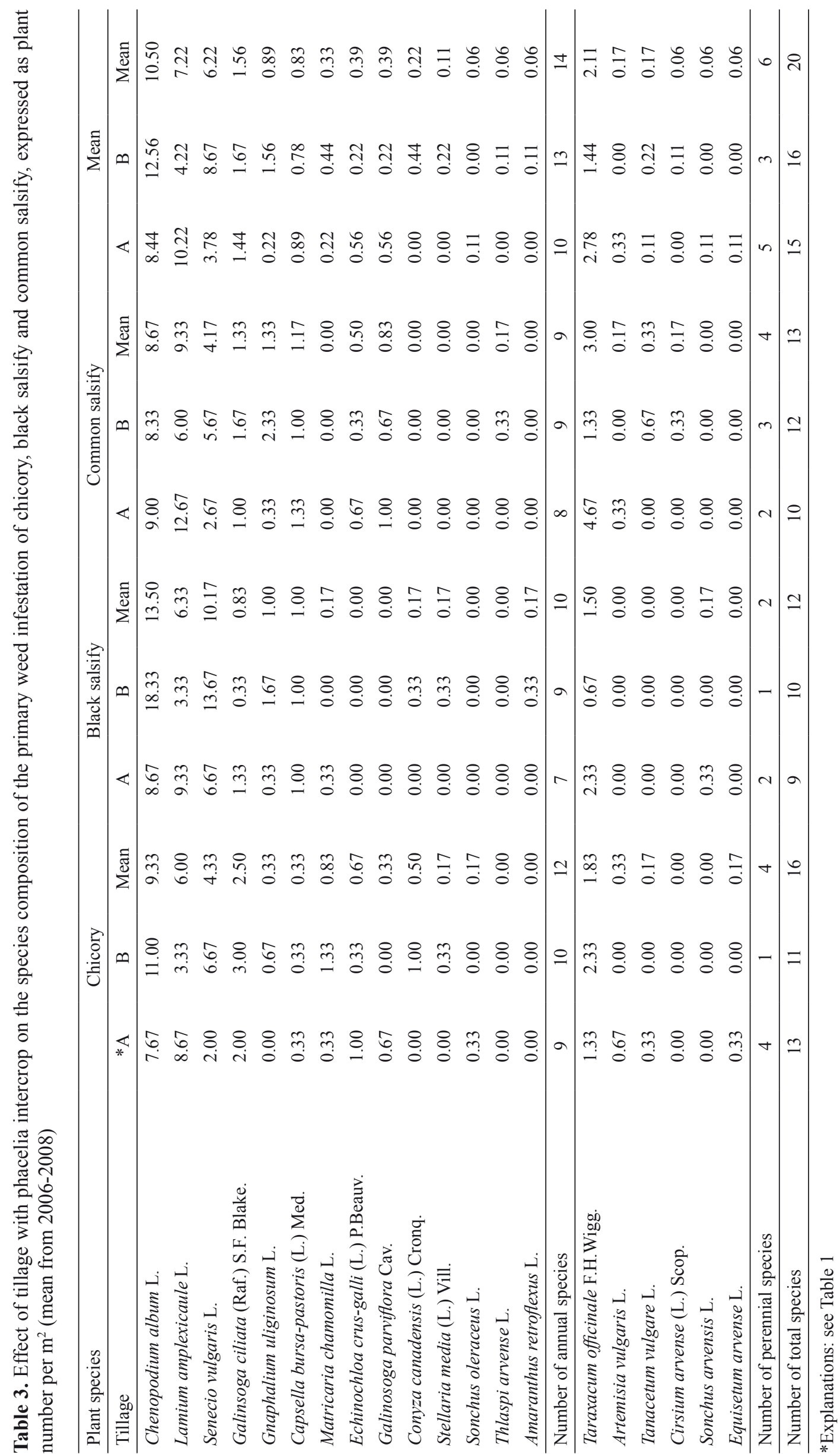


soils was observed. The presence of Elymus repens in ridge cultivation can be also explained by the fact that the soil in a ridge is looser and better aerated, which makes good conditions for couch grass runner growth.

Ridge cultivation decreased the primary weed infestation in vegetable crops from 44.4 plants per $\mathrm{m}^{2}$ in flat soil to 33.2 plants in the ridge cultivation system (Tab. 4). Weed seed germination in dry soil is more difficult (Dobrzański 2009), therefore a larger number of weeds can usually be found in rainy summers or on heavy soils in ridge cultivation. The influence of ridge cultivation on weed number was prominent when plants grew without an intercrop.
In plants grown in the traditional way (i.e. in flat soil and without phacelia), the average number of weeds was 55.7 plants per $\mathrm{m}^{2}$, whereas there were only 36.6 plants in the ridge system. When phacelia biomass was covered by ploughing before winter, the influence of ridge formation on primary weed infestation was not as obvious.

When comparing the species composition of the primary weed infestation among the studied vegetable crops, no differences in the number of weed species grown (from 12 to 14 taxa) were recorded. The same species dominated in all of the cultivation combinations, and their number was more modified by the phacelia intercrop application

Table 4. Effect of tillage and intercrop on the size of the primary weed infestation of chicory, black salsify and common salsify (plants per $\mathrm{m}^{2}$ ) in the years 2006-2008

\begin{tabular}{|c|c|c|c|c|c|c|c|c|c|c|c|c|c|}
\hline \multirow{3}{*}{ Factors } & & \multicolumn{3}{|c|}{ Chicory } & \multicolumn{3}{|c|}{ Black salsify } & \multicolumn{3}{|c|}{ Common salsify } & \multicolumn{3}{|c|}{ Mean } \\
\hline & & $* S$ & $* \mathrm{P}$ & Total & $\mathrm{S}$ & $P$ & Total & $\mathrm{S}$ & $P$ & Total & $\mathrm{S}$ & $P$ & Total \\
\hline & & \multicolumn{12}{|c|}{ Number of weeds per $\mathrm{m}^{2}$} \\
\hline & & \multicolumn{12}{|c|}{ Tillage without intercrop } \\
\hline \multirow{2}{*}{ Tillage } & Ridges & 48.7 & 6.0 & 54.7 & 28.3 & 3.3 & 31.6 & 17.7 & 5.6 & 23.3 & 31.6 & 5.0 & 36.6 \\
\hline & Flat & 53.0 & 5.3 & 58.3 & 47.3 & 3.0 & 50.3 & 55.3 & 3.3 & 58.6 & 51.9 & 3.8 & 55.7 \\
\hline \multirow{3}{*}{ Years } & 2006 & 26.5 & 4.0 & 30.5 & 32.5 & 4.0 & 36.5 & 32.2 & 4.5 & 36.7 & 30.4 & 4.2 & 34.6 \\
\hline & 2007 & 20.0 & 3.5 & 23.5 & 15.0 & 2.0 & 17.0 & 12.0 & 4.0 & 16.0 & 15.7 & 3.2 & 18.8 \\
\hline & 2008 & 106.0 & 9.5 & 115.5 & 66.0 & 3.5 & 69.5 & 65.4 & 5.0 & 70.4 & 79.1 & 6.0 & 85.1 \\
\hline \multirow[t]{2}{*}{ Mean } & & 50.8 & 5.7 & 56.5 & 37.8 & 3.2 & 41.0 & 36.5 & 4.5 & 41.0 & 41.7 & 4.4 & 46.2 \\
\hline & & \multicolumn{12}{|c|}{ Tillage with phacelia intercrop } \\
\hline \multirow[t]{2}{*}{ Tillage } & Ridges & 23.0 & 2.7 & 25.7 & 27.7 & 2.6 & 30.3 & 28.7 & 5.0 & 33.7 & 26.4 & 3.4 & 29.8 \\
\hline & Flat & 28.0 & 2.3 & 30.3 & 39.3 & 0.7 & 40.0 & 26.3 & 2.3 & 28.6 & 31.2 & 1.8 & 33.0 \\
\hline \multirow[t]{3}{*}{ Years } & 2006 & 28.0 & 5.0 & 33.0 & 34.0 & 1.5 & 35.5 & 23.5 & 6.0 & 29.5 & 28.5 & 4.2 & 32.7 \\
\hline & 2007 & 11.5 & 2.5 & 14.0 & 11.5 & 1.0 & 12.5 & 9.5 & 2.0 & 11.5 & 10.8 & 1.8 & 12.7 \\
\hline & 2008 & 37.0 & 0.0 & 37.0 & 55.0 & 2.5 & 57.5 & 49.5 & 3.0 & 52.5 & 47.2 & 1.8 & 49.0 \\
\hline \multirow[t]{2}{*}{ Mean } & & 25.5 & 2.5 & 28.0 & 33.5 & 1.7 & 35.2 & 27.5 & 3.7 & 31.2 & 28.8 & 2.6 & 31.4 \\
\hline & & \multicolumn{12}{|c|}{ Mean } \\
\hline \multirow[t]{2}{*}{ Tillage } & Ridges & 35.9 & 4.4 & 40.2 & 28.0 & 3.0 & 31.0 & 23.2 & 5.3 & 28.5 & 29.0 & 4.2 & 33.2 \\
\hline & Flat & 40.5 & 3.8 & 44.3 & 43.3 & 1.9 & 45.2 & 40.8 & 2.8 & 43.6 & 41.6 & 2.8 & 44.4 \\
\hline \multirow[t]{3}{*}{ Years } & 2006 & 27.3 & 4.5 & 31.8 & 33.3 & 2.8 & 36.0 & 27.9 & 5.3 & 33.1 & 29.5 & 4.2 & 33.6 \\
\hline & 2007 & 15.8 & 3.0 & 18.8 & 13.3 & 1.5 & 14.8 & 10.8 & 3.0 & 13.8 & 13.3 & 2.5 & 15.8 \\
\hline & 2008 & 71.5 & 4.8 & 76.3 & 60.5 & 3.0 & 63.5 & 57.5 & 4.0 & 61.5 & 63.2 & 3.9 & 67.1 \\
\hline Mean & & 38.2 & 4.1 & 42.3 & 35.7 & 2.4 & 38.1 & 32.0 & 4.1 & 36.1 & 35.3 & 3.5 & 38.8 \\
\hline \multicolumn{14}{|c|}{$\mathrm{LSD}_{0.05}$ for: } \\
\hline tillage & & n.s. & n.s. & n.s. & n.s. & n.s. & n.s. & n.s. & n.s. & 9.1 & 8.7 & n.s. & 10.3 \\
\hline intercrop & & n.s. & n.s. & 13.1 & n.s. & n.s. & n.s. & n.s. & n.s. & 9.1 & 8.7 & n.s. & 10.3 \\
\hline species & & - & - & - & - & - & - & - & - & - & n.s. & n.s. & n.s. \\
\hline years & & n.s. & n.s. & 24.5 & n.s. & n.s. & 17.1 & n.s. & n.s. & 16.9 & 19.6 & n.s. & 20.9 \\
\hline
\end{tabular}

${ }^{*} \mathrm{~S}$ - annual weeds, $\mathrm{P}$ - perennial weeds, n.s. - no significant differences 
than the vegetable species itself. No significant differences in the amount of primary weed infestation in chicory, black salsify or phacelia were observed. The number of both short-term and perennial weed species in these cultivations was similar. Differences in the primary weed infestation were present in subsequent years of the experiment. The largest number of weeds grew in the field in 2008, while the lowest was in 2007.

\section{Secondary weed infestation}

In autumn, the weed infestation in vegetables plots increased as compared to the primary weed number (Tabs 5 and 6). In total, 31 weed taxa were recorded. The number of short-term species increased to 22, while perennial ones to nine. Capsella bursa-pastoris (L.) Medik. and Stellaria media, which flower and fruit massively throughout the year, dominated. Urtica urens L., which can produce seeds able to germinate even 5-7 weeks after emergence, appeared quite numerously (Dobrzański 2009). Compared to the spring, the populations of Chenopodium album, Senecio vulgaris and Lamium amplexicaule decreased. Riemens et al. (2004) reported that these species require light, because the light deficiency reduces their emergence remarkably. In turn, poor light had no significant impact on the emergence of Urtica urens in studies performed by Andersson et al. (1997), which could explain its occurrence in the secondary weed population, when spaces were shielded by vegetable leaves. Among the perennials, the number of Taraxacum officinale decreased, while new species appeared, e.g. Epilobium adenocaulon Hausskn. and Urtica dioica L., which are a typical species within vegetable crops and the Polygono-Chenopodietalia order (R.Tx. et Lohm. 1950) J.Tx. 1961 (Matuszkiewicz 2008), and belong to orchard and ruderal habitats, similar to Conyza canadensis, Erigeron annuus L., Artemisia vulgaris or Tanacetum vulgare L. (Lisek 1998).

The phacelia intercrop lowered the number of monocarpic weed species by four as compared to the cultivation without any intercrop. Chenopodium glaucum L., Erigeron annuus L., Galium aparine L., Lamium purpureum L., Polygonum persicaria L. and Solanum nigrum L. were absent, whereas Thlaspi arvense L. and Plantago maior L., which had not grown before in the control cultivation, were recorded. The positive influence of phacelia on the reduction of weed numbers was weakened when compared to the initial vegetable vegetation period, and no considerable decrease of weed number was recorded in crops where the intercrop was applied before winter. Only a tendency to larger weed infestation in vegetables grown without an intercrop was observed.

The number of weed species grown in ridges increased in relation to the spring and it was even higher on flat soil, both with and without the intercrop, but no univocal regularity in particular species occurrence was found. Artemisia vulgaris was more abundant in ridges rather than in the flat soil system, while Taraxacum officinale was more frequent in traditional cultivation. Ridges make specific growing conditions for weeds. Taxa with higher water requirements grow in better-wetted furrows between ridges, while those requiring more warmth and light grow better on ridge tops. The higher weed numbers in the furrow result from a more abundant seed bank in that part of the ridge profile (Dobrzański 2009). The tillage system had no significant effect on the number of secondary weeds in the studied vegetable species. Unlike in the spring, slightly more weeds were grown in ridges than on flat soil, which can be explained by the strong shading of the spaces by vegetables that were grown in the traditional manner, in flat soil system.

The species of cultivated plant significantly affected the secondary weed infestation (Tab. 7). The largest amount of weeds grew in black salsify (30.8 plants per $\mathrm{m}^{2}$ ) and common salsify (21.8 plants), while the smallest was found in chicory cultivation (only 2.2 plants). Well-leaved plants efficiently shaded the soil, making weed growth impossible. The leaf rosettes of black and common salsify with more fragile and narrow leaves were not capable of reducing the weed numbers to the same degree. In particular, many weeds in these vegetable species were recorded in the nointercrop cultivations. When the phacelia biomass was ploughed, the number of secondary weeds in black and common salsify decreased. In the case of chicory, the secondary weed infestation was so low that the influence of other experimental factors was not prominent.

No differences in the secondary weed infestation level were recorded in the studied vegetable species in the different experimental years. The influence of experimental factors, namely the crop species, on weed number was greater than the differences in weather conditions between the different years of the study. 


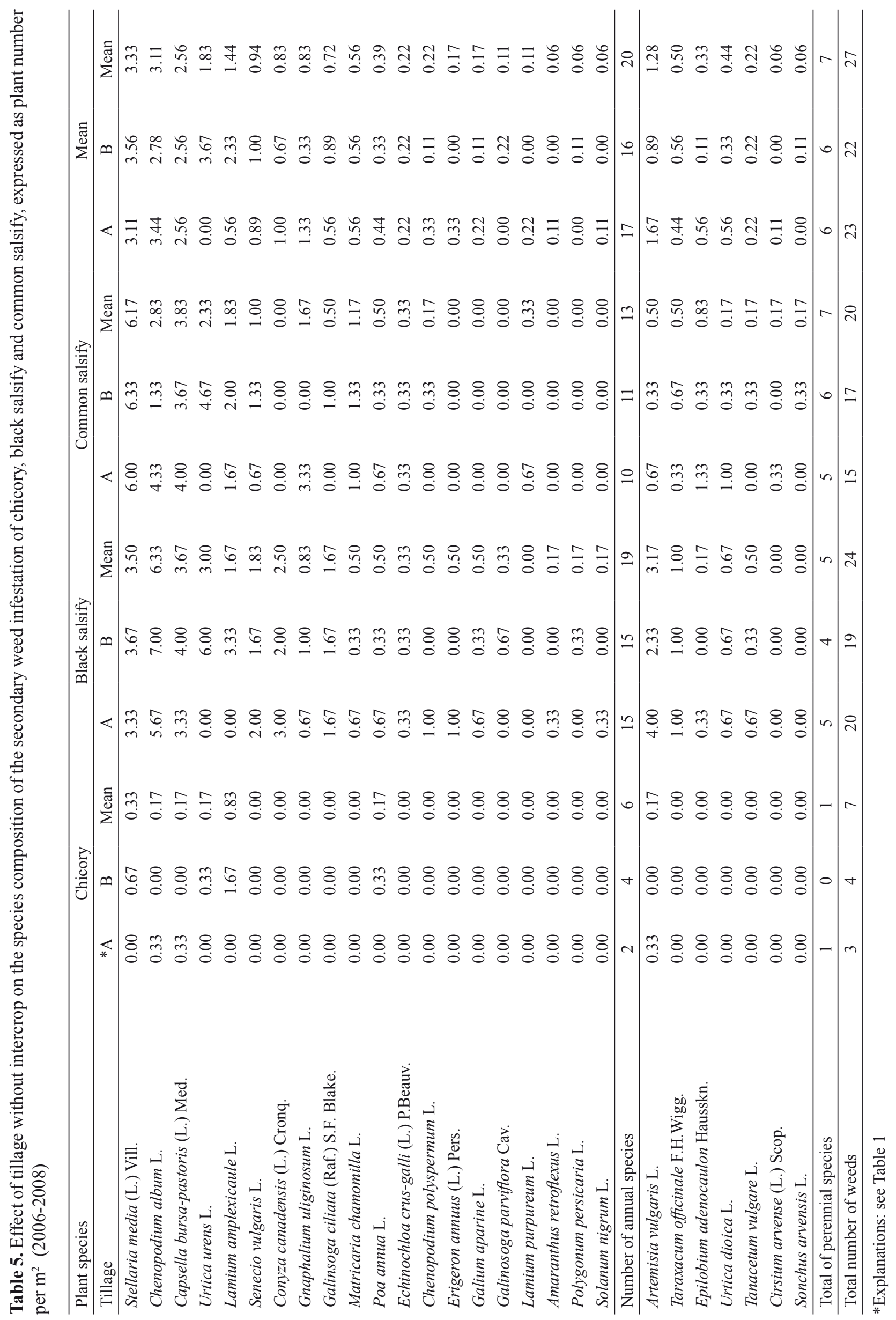




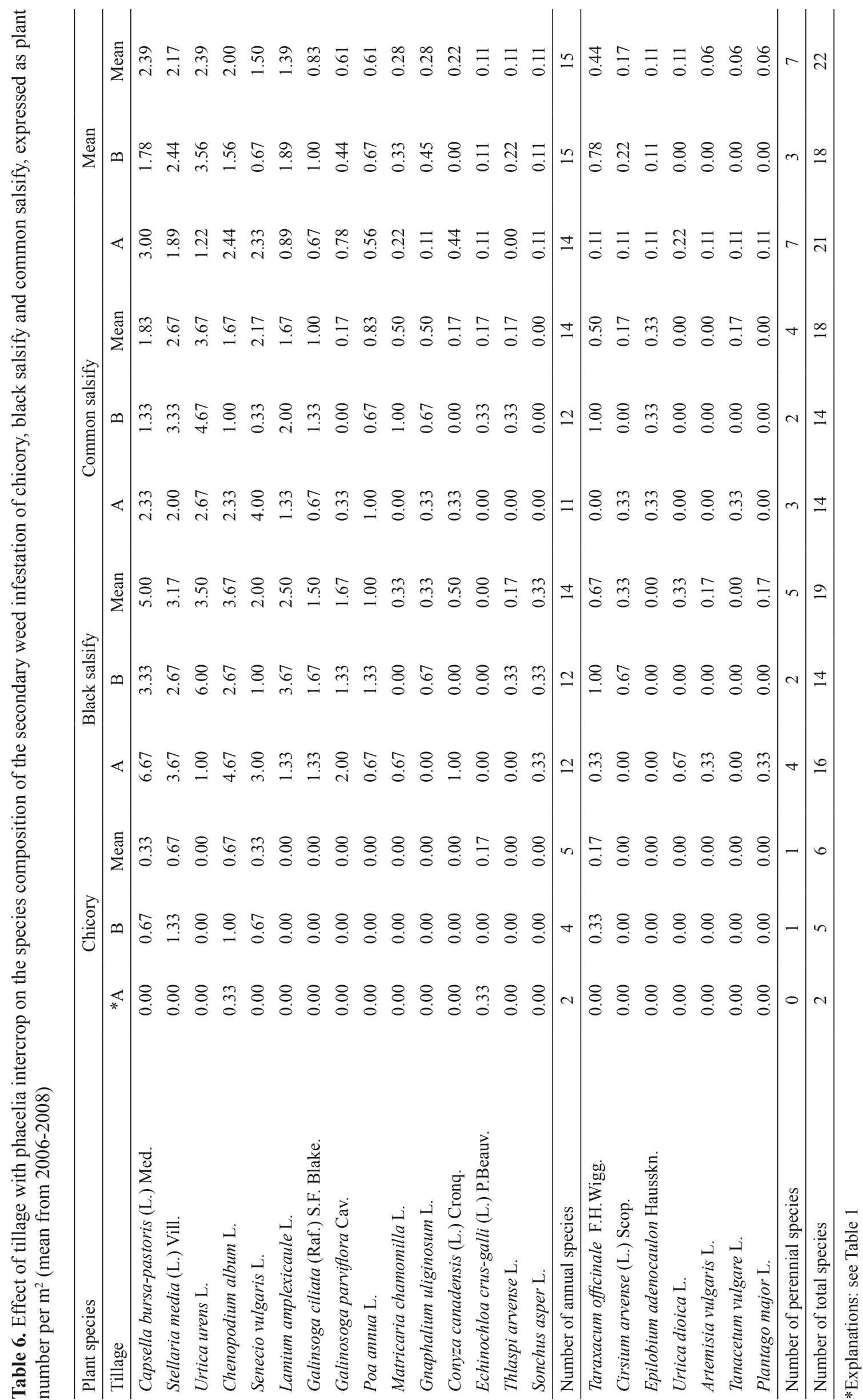


Table 7. Effect of tillage and intercrop on the size of the secondary weed infestation of chicory, black salsify and common salsify (plants per $\mathrm{m}^{2}$ ) in the years 2006-2008

\begin{tabular}{|c|c|c|c|c|c|c|c|c|c|c|c|c|c|}
\hline \multirow{3}{*}{ Factors } & & \multicolumn{3}{|c|}{ Chicory } & \multicolumn{3}{|c|}{ Black salsify } & \multicolumn{3}{|c|}{ Common salsify } & \multicolumn{3}{|c|}{ Mean } \\
\hline & & $* \mathrm{~S}$ & $* \mathrm{P}$ & Total & $\mathrm{S}$ & $P$ & Total & $\mathrm{S}$ & $\mathrm{P}$ & Total & $\mathrm{S}$ & $\mathrm{P}$ & Total \\
\hline & & \multicolumn{12}{|c|}{ Number of weeds per $\mathrm{m}^{-2}$} \\
\hline & & \multicolumn{12}{|c|}{ Tillage without intercrop } \\
\hline \multirow{2}{*}{ Tillage } & Ridges & 0.7 & 0.3 & 1.0 & 24.7 & 6.6 & 31.3 & 22.7 & 3.6 & 26.3 & 16.0 & 3.6 & 19.6 \\
\hline & Flat & 3.0 & 0.0 & 3.0 & 32.7 & 4.3 & 37.0 & 22.7 & 2.3 & 25.0 & 19.4 & 2.2 & 21.6 \\
\hline \multirow{3}{*}{ Years } & 2006 & 2.5 & 0.0 & 2.5 & 32.0 & 15.5 & 47.5 & 7.5 & 4.1 & 11.6 & 14.0 & 6.5 & 20.5 \\
\hline & 2007 & 2.5 & 0.0 & 2.5 & 27.5 & 1.0 & 28.5 & 31.0 & 3.2 & 34.2 & 20.3 & 1.4 & 21.7 \\
\hline & 2008 & 0.5 & 0.5 & 1.0 & 26.5 & 0.0 & 26.5 & 29.5 & 1.6 & 31.1 & 18.8 & 0.7 & 19.5 \\
\hline \multirow[t]{2}{*}{ Mean } & & 1.8 & 0.2 & 2.0 & 28.7 & 5.5 & 34.2 & 22.7 & 2.5 & 25.2 & 17.7 & 2.9 & 20.6 \\
\hline & & \multicolumn{12}{|c|}{ Tillage with phacelia intercrop } \\
\hline \multirow[t]{2}{*}{ Tillage } & Ridges & 0.7 & 0.0 & 0.7 & 26.3 & 1.7 & 28.0 & 17.3 & 1.0 & 18.3 & 14.8 & 0.9 & 15.7 \\
\hline & Flat & 3.7 & 0.3 & 4.0 & 25.0 & 1.7 & 26.7 & 17.0 & 1.3 & 18.3 & 15.2 & 1.1 & 16.3 \\
\hline \multirow[t]{3}{*}{ Years } & 2006 & 0.0 & 0.0 & 0.0 & 18.0 & 3.5 & 21.5 & 11.5 & 2.5 & 14.0 & 9.8 & 2.0 & 11.8 \\
\hline & 2007 & 6.0 & 0.6 & 6.6 & 25.5 & 1.6 & 27.1 & 16.0 & 0.5 & 16.5 & 15.8 & 0.9 & 16.7 \\
\hline & 2008 & 0.5 & 0.0 & 0.5 & 33.5 & 0.0 & 33.5 & 24.0 & 0.5 & 24.5 & 19.3 & 0.2 & 19.5 \\
\hline \multirow[t]{2}{*}{ Mean } & & 2.2 & 0.2 & 2.4 & 25.7 & 1.7 & 27.4 & 17.2 & 1.2 & 18.3 & 15.0 & 1.0 & 16.0 \\
\hline & & \multicolumn{12}{|c|}{ Mean } \\
\hline \multirow[t]{2}{*}{ Tillage } & Ridges & 0.7 & 0.2 & 0.9 & 25.5 & 4.2 & 29.7 & 20.0 & 2.3 & 22.3 & 15.4 & 2.3 & 17.7 \\
\hline & Flat & 3.4 & 0.2 & 3.5 & 28.9 & 3.0 & 31.9 & 19.9 & 1.8 & 21.7 & 17.3 & 1.7 & 19.0 \\
\hline \multirow[t]{3}{*}{ Years } & 2006 & 1.3 & 0.0 & 1.3 & 25.0 & 9.5 & 34.5 & 9.5 & 3.3 & 12.8 & 11.9 & 4.3 & 16.2 \\
\hline & 2007 & 4.3 & 0.3 & 4.6 & 26.5 & 1.3 & 27.8 & 23.5 & 1.9 & 25.4 & 18.1 & 1.2 & 19.2 \\
\hline & 2008 & 0.5 & 0.3 & 0.8 & 30.0 & 0.0 & 30.0 & 26.8 & 1.1 & 27.8 & 19.1 & 0.4 & 19.5 \\
\hline Mean & & 2.0 & 0.2 & 2.2 & 27.2 & 3.6 & 30.8 & 20.0 & 1.9 & 21.8 & 16.4 & 2.0 & 18.3 \\
\hline \multicolumn{14}{|c|}{$\mathrm{LSD}_{0.05}$ for: } \\
\hline tillage & & n.s & n.s & $\mathrm{n} . \mathrm{s}$ & $\mathrm{n} . \mathrm{s}$ & $\mathrm{n} . \mathrm{s}$ & n.s & n.s & n.s & n.s & n.s. & n.s. & n.s. \\
\hline intercrop & & n.s. & n.s. & n.s. & n.s. & n.s. & n.s. & n.s. & n.s. & n.s. & n.s. & 0.6 & n.s \\
\hline species & & - & - & - & - & - & - & - & - & - & 12.6 & 0.9 & 12.9 \\
\hline years & & n.s. & n.s. & n.s. & n.s. & 2.5 & n.s. & n.s. & n.s. & n.s. & n.s. & 0.9 & n.s. \\
\hline
\end{tabular}

*S - annual weeds, $\mathrm{P}$ - perennial weeds, n.s. - no significant differences

\section{CONCLUSIONS}

1. In total, 24 taxa in the primary and 31 taxa in the secondary weed infestation (mostly characteristic for vegetable crops) were recorded in high-inulin species plantations. Monocarpic species with the most numerous; Senecio vulgaris, Chenopodium album and Lamium amplexicaule dominated in the spring, while Stellaria media, Capsella bursa-pastoris and Urtica urens dominated at the end of the vegetation period.

2. Applying phacelia as an intercrop and ploughing its biomass before winter significantly reduced the primary weed population for all of the cultivated crop species as compared to the nointercrop cultivations.

3. Phacelia grown as an intercrop reduced the occurrence of Senecio vulgaris, while favouring the growth of Lamium amplexicaule.

4. The cultivation system affected the primary weed infestation of vegetables, whereas it had no impact on the secondary weed population level. At the beginning of the vegetation periods, fewer weeds grew in ridges than in the flat soil system.

5. The crop species had no effects on the primary weed population, while it influenced the secondary weed infestation. The lowest numbers of weeds were recorded in the secondary weed 
infestation in chicory, the well-developed leaf rosettes of which efficiently eliminated most of the weeds.

\section{ACKNOWLEDGEMENTS}

Research financed by the Ministry of Science and Higher Education within the framework of project No 2P06R 01429.

\section{REFERENCES}

Adamicki F., Nawrocka B., DobrZaŃSkiA., FelczyŃSki K., Robak J., Szwejda J., 2005. Metodyka integrowanej produkcji marchwi. PIORIN Warszawa.

Andersson L., Milberg P., Noronha A., 1997. Germination response of weed seeds to light, light of short duration and darkness after stratification in soil. Swedish J. Agric. 27: 113-120.

Anyszka Z., Dobrzański A., 2008. Changes in weed infestation in transplanted leek grown in organic mulch. Prog. Plant Prot. 48(4): 1391-1395.

Babik J., Adamicki F., Anyszka Z., Robak J., Szwejda J., 2004. Ekologiczne metody uprawy marchwi. Krajowe Centrum Rolnictwa Ekologicznego, Radom, ISBN 83-89060-33-7.

BŁAżEWICZ-WoźNIAK M., 2003. Weed infestation of onion in soil reduced cultivation system. Acta Agrobot. 56(1/2): 135-148.

BŁażewicz-Woźniak M., 2004. Primary weed infestation of carrot in conservation tillage. Acta Sci. Pol., Hortorum Cultus 3(1): 165-174.

BŁażewicz-Woźniak M., Mitura R., 2004. Influence of conservation tillage on contents of mineral components in soil and parsley roots. Roczn. AR Pozn. CCCLVI, Ogrodnictwo 37: 3-11.

Carter M.R., Ivany J.A., 2006. Weed seed bank composition under three long-term tillage regimes on a fine sandy loam in Atlantic Canada. Soil Till. Res. 90: 29-38.

DobrZAŃSKi A., 2009. Biologiczne i agrotechniczne aspekty regulowania zachwaszczenia. Ekspertyza. AgEngPol.

Dhimaa K.V., Vasilakogloub I.B., Gatsisa Th.D., Panou-Philotheoua E., Eleftherohorinosc I.G., 2009. Effects of aromatic plants incorporated as green manure on weed and maize development. Field Crops Res. 110: 235-241.

Franczuk J., JabŁońska-Ceglarek R., ZaniewiczBAjkowska A., Rosa R., 2008. Infestation and moisture soil influenced by plants mulch. Ochrona Środowiska i Zasobów Naturalnych 35/36: 166-172.

Franczuk J., Kosterna E., Zaniewicz-Bajkowska A., 2010. Weed-control effects on different types of cover-crop mulches. Acta Agric. Scandin., Section B - Plant Soil Sci. 1651-1913, 60, 5: 472-479.

Kęsik T., BŁażewicz-Woźniak M., 2007. The effect of cover crop mulches and reduced soil tillage in onion cultivation on some features of soil. Roczn. AR w Poznaniu CCCLXXXIII, Ogrodnictwo. 41: 517-521.

Kęsik T., BŁażewicz-Woźniak M., Wach D., 2010. Influence of conservation tillage in onion production on the soil organic matter content and soil aggregate formation. Int. Agrophysics, 24: 1-7.

Khalid S., Ahmad T., Shad R.A., 2002. Use of allelopathy in Agriculture. Asian J. Plant Sci. 1(3): 292-297.

KoNOPIŃSKi M., 2003. Wpływ zróżnicowanych systemów uprawy na kształtowanie warunków wzrostu, plonowanie i wartość biologiczną skorzonery (Scorzonera hispanica L.). Rozpr. Nauk. AR Lublin.

Konopiński M., BŁażewicz-WoźniaK M., 2008. Effect of differentiated pre-sowing soil tillage and intercrops on the emergence and yield of root plants. Zesz. Probl. Post. Nauk Rol. 527: 155-163.

Krause U., Koch H.J., Maerlaender B., 2009. Soil properties effecting yield formation in sugar beet under ridge and flat cultivation. Europ. J. Agron. 31: 20-28.

Liebman M., Dyck E., 1993. Crop rotation and intercropping strategies for weed management. Ecol. Appl. (3)1: 92-122.

LiseK J., 1998. Chwasty i ich zwalczanie w sadach i jagodnikach. Hortpress, Warszawa.

Matuszkiewicz W., 2008. Przewodnik do oznaczania zbiorowisk roślinnych Polski. PWN, Warszawa.

Mcgiffen Jr., M.E., Ehlers J.D., Aguiar J.L., 2000. Introduction to organic horticulture colloquium. HortTech. 10: 661-662.

Ngouajioa M., Mcgiffen M.E. JR, Hutchinsonc C.M., 2003. Effect of cover crop and management system on weed populations in lettuce. Crop Prot. 22: 57-64.

PŁaza A., Ceglarek F., Królikowska M.A., 2008. The role of intercrops in reduction of weed infestation of potato plantations. Prog. Plant Prot. 48(4): 14661469.

Riemens M.M., Scheepens P.C., Weide Van Der R.Y., 2004. Dormancy, germination and emergence of weed seeds, with emphasis on the influence of light. Plant Res. Intern. B.V., Wageningen, 302: 46.

Rola J., Rola H., 1996. Ekspansywne chwasty segetalne w uprawach rolniczych w Polsce. Zesz. Nauk. ATR w Bydgoszczy, Rolnictwo 196(38): 17-22.

Sady W., Cebulak T., 2000. Effect of cultivation methods on nutritive compounds in the carrot. Folia Hort. 12(1): 77-84.

Teasdale J.R., Brandsaeter L.O., Calegari A., Neto F.S., 2007. Chapter 4. Cover crops and weed management. In: Non-chemical weed management principles, concepts and technology. M.K. Upadhyaya, R.E. Blackshaw (eds), Wallingford, UK, CABI: 49-64.

WesoŁowski M., 1981. Zanieczyszczenie diasporami chwastów ważniejszych jednostek glebowych w makroregionie południowo-wschodnim i środkowym Polski. Rozpr. Nauk. AR w Lublinie 70, 42. 


\section{WPEYW UPRAWY NA REDLINACH \\ I MIĘDZYPLONU Z FACELII NA \\ ZACHWASZCZENIE WARZYW}

KORZENIOWYCH Z RODZINY ASTERACEAE

Streszczenie: W doświadczeniu polowym z uprawą trzech gatunków warzyw korzeniowych o wysokiej zawartości inuliny: cykoria korzeniowa (Cichorium intybus L. var. sativum Bisch.), skorzonera (Scorzonera hispanica L.) i salsefia (Tragopogon porrifolius L.) uwzględniono dwie metody uprawy: uprawę płaską i na redlinach a także zastosowano międzyplon z facelii błękitnej (Phacelia tanacetifolia L.), której biomasa została wymieszana z glebą orką przedzimową. Kontrolę stanowiła uprawa bez międzyplonu. Celem badań, było określenie wpływu uprawy na redlinach przy zastosowaniu międzyplonu $\mathrm{z}$ facelii na skład gatunkowy i liczebność zachwaszczenia warzyw, $\mathrm{w}$ porównaniu $\mathrm{z}$ tradycyjną uprawą płaską bez międzyplonu. W zachwaszczeniu pierwotnym oznaczono łącznie 24 taksony a w zachwaszczeniu wtórnym 31, w większości charakterystycznych dla upraw warzywnych.
Dominowały gatunki monokarpiczne, wśród których wiosną najliczniej występowały Senecio vulgaris, Chenopodium album i Lamium amplexicaule, a pod koniec wegetacji: Stellaria media, Capsella bursa-pastoris i Urtica urens. Zastosowanie facelii, jako rośliny międzyplonowej i przyoranie jej biomasy przed zima, istotnie ograniczyło stopień zachwaszczenia pierwotnego wszystkich uprawianych gatunków w porównaniu $\mathrm{z}$ uprawą bez międzyplonu. Facelia zastosowana w międzyplonie ograniczyła występowanie Senecio vulgaris a sprzyjała Lamium amplexicaule. System uprawy roli wpłynął na stopień zachwaszczenia pierwotnego warzyw, ale nie oddziaływał na zachwaszczenie wtórne. $\mathrm{Na}$ początku wegetacji na redlinach rosło mniej chwastów niż w uprawie płaskiej. Gatunek rośliny uprawnej nie wpłynął na liczebność zachwaszczenia pierwotnego natomiast oddziaływał na zachwaszczenie wtórne. Najmniej chwastów oznaczono w zachwaszczeniu wtórnym cykorii, której dobrze rozwinięte rozety liściowe skutecznie wyeliminowały chwasty.

Received April 1, 2011; accepted March 30, 2012 